\title{
MULTILINGUALISM IN FINNISH SCHOOLS: POLICIES AND PRACTICES
}

\author{
Sirkku Latomaa ${ }^{1}$ and Minna Suni ${ }^{2}$ \\ ${ }^{1}$ University of Tampere and ${ }^{2}$ University of Jyväskylä
}

\begin{abstract}
This article provides an overview of multilingualism in Finnish schools. The focus is on the experiences gathered from the teachers of plurilingual students, i.e. students from immigrant backgrounds. The data in our study were collected by administering a web questionnaire, and the topics covered, for example, the status of languages and the teaching arrangements tailored for plurilingual students. In addition to reacting to the questionnaire's statements, the respondents could freely comment on any of the topics, which enriched the quantitative data by offering many useful perspectives. Several respondents reported that during their working careers, noticeable progress has been made accommodating plurilingual students. On the other hand, the results showed that several challenges still remain, such as assuring a more uniform provision of L1 and L2 instruction. In some regions of Finland, such programmes have been functioning well, but in others, administrators are only just awakening to the increasing multilingualism in their schools.
\end{abstract}

Keywords: multilingualism, language education, immigration, language attitudes, first language, second language

\section{Introduction}

The linguistic situation in Finland has changed quite dramatically during the past few decades. In the beginning of the 1990s, Finland received more refugees than before, and the collapse of the Soviet Union led to a rapid increase of immigration by former Soviet citizens. More recently, the number of both asylum seekers and work-related immigrants has increased notably. As a result, all levels of the Finnish educational system have been forced to accommodate the rapidly increasing plurilingualism among students.

As the linguistic diversity in Finnish schools has grown, the interest in research on the implementation of educational 
policies has increased accordingly. Most studies so far have concentrated on the arrangements made and the school success of immigrant students as exemplified, for instance, in statistics and other information provided by municipalities and headmasters (Kuusela et al. 2008, Laaksonen 2008, Kuukka 2009, Lasonen and Halonen 2009). Less attention has been paid to the reasons behind the challenges encountered, nor have the teachers of immigrant students often been used as a source of information. In order to map how the current language education policies are implemented in practice, we conducted a web-survey among teachers of immigrant students as part of our on-going study entitled, How is multilingualism perceived and practised in Finnish schools? This article reports some of the findings (see also Suni and Latomaa, forthcoming). The current focus will be on the status of L1 and L2 instruction in the national core curriculum on the one hand, and on their status in various schools, on the other. Special attention will be paid to the educational arrangements and how they are valued by plurilingual students and their parents.

In this study, students from immigrant backgrounds are referred to as plurilinguals to emphasise the fact that they use two or more languages in their daily lives. Individual plurilingualism is thus differentiated from societal multilingualism, the multilingual nature of a given society, in accordance with the terminology adopted by the Council of Europe. ${ }^{1}$

In the following section, an overview of the linguistic situation in Finland and Finnish schools will be provided leading on to a brief presentation of the general guidelines for L1 and L2 instruction. Based on our research project findings, we will then discuss the following questions: What is the status of immigrant languages in the daily school life seen against the national language education policies? What is the general status of Finnish as a second language (FSL) instruction from the standpoint of teachers, students and parents? To conclude we will summarise the main observations and evaluate the current situation in Finnish schools.

\footnotetext{
${ }^{1}$ Members of the majority could also be called plurilingual. In addition to their first language, they have knowledge of foreign languages. In this article, however, this term refers only to students from immigrant backgrounds.
} 


\section{Linguistic diversity in Finland and Finnish schools}

The Nordic region became a target for immigration after WWII. Immigration to Sweden started in the 1950s, with immigration to Denmark and Norway increasing in the 1970s. Finland, however, turned into an immigrant country relatively late, as did Iceland. In Finland the number of immigrants exceeded the number of emigrants for the first time in 1981.

When estimating the size of the immigrant population, various measures are taken in the Nordic region. In Sweden, Norway, Denmark and Iceland it is customary to combine two generations: those who were born abroad and who actually immigrated to the country in question and, in addition, those born in the country and whose parents are foreign-born. The statistics collected according to this method of categorisation indicate that the multilingual profiles of the Nordic countries differ slightly (Table 1):

Table 1. The percentage of the immigrant population in four Nordic countries (Statistics Sweden 2011, Statistics Norway 2011, Statistics Denmark 2011, Statistics Iceland 2011).

\begin{tabular}{|r|l|r|r|}
\hline \multicolumn{1}{|l|}{ Date } & Country & Total Population & Immigrants (\%) \\
\hline 31.12 .2010 & Sweden & $9,415,570$ & 19.1 \\
\hline 1.1 .2011 & Norway & $4,920,305$ & 12.2 \\
\hline 1.1 .2011 & Denmark & $5,560,628$ & 10.2 \\
\hline 1.1 .2011 & Iceland & 318,452 & 8.9 \\
\hline
\end{tabular}

While Sweden is clearly the most multilingual and multicultural country in both absolute numbers and in proportion, the statistics illustrate that in the other three Nordic countries - Norway, Denmark and Iceland - the proportion of immigrant population is comparatively similar. The official statistics in Finland, however, do not combine the two generations and therefore Finland cannot be included within the same comparison. According to a study (Martikainen 2007) where the Nordic definition was adopted, it was determined that approximately $6 \%$ of the people in Finland come from an immigrant background.

Currently, the national statistics centre, Statistics Finland, publishes statistics on citizenship, country of birth and the 
"mother tongue" of the population in Finland. According to these statistics, at the end of 2010 there were 167954 foreign citizens, 224388 inhabitants with a first language other than Finnish, Swedish or Sámi, and 248135 inhabitants who were born outside Finland (Statistics Finland 2011). It is well-known, however, that none of these figures accurately reflects the current situation, since they no longer capture what is called the second generation: as they were born in Finland, they may be Finnish citizens, and they often report Finnish as their first language. As a consequence, it is not possible to get an overview of the extensiveness of multilingualism in Finland with the help of current measures.

Nevertheless, some features of Finland's linguistic profile can be characterised on the basis of the available language statistics (Statistics Finland 2011). At the beginning of 2011, more than 150 languages were used in Finland. As many as 34 of them had more than 1,000 speakers. Figure 1 shows the languages with the largest number of speakers in Finland, and illustrates the growth in the number of speakers during the past 10 years.

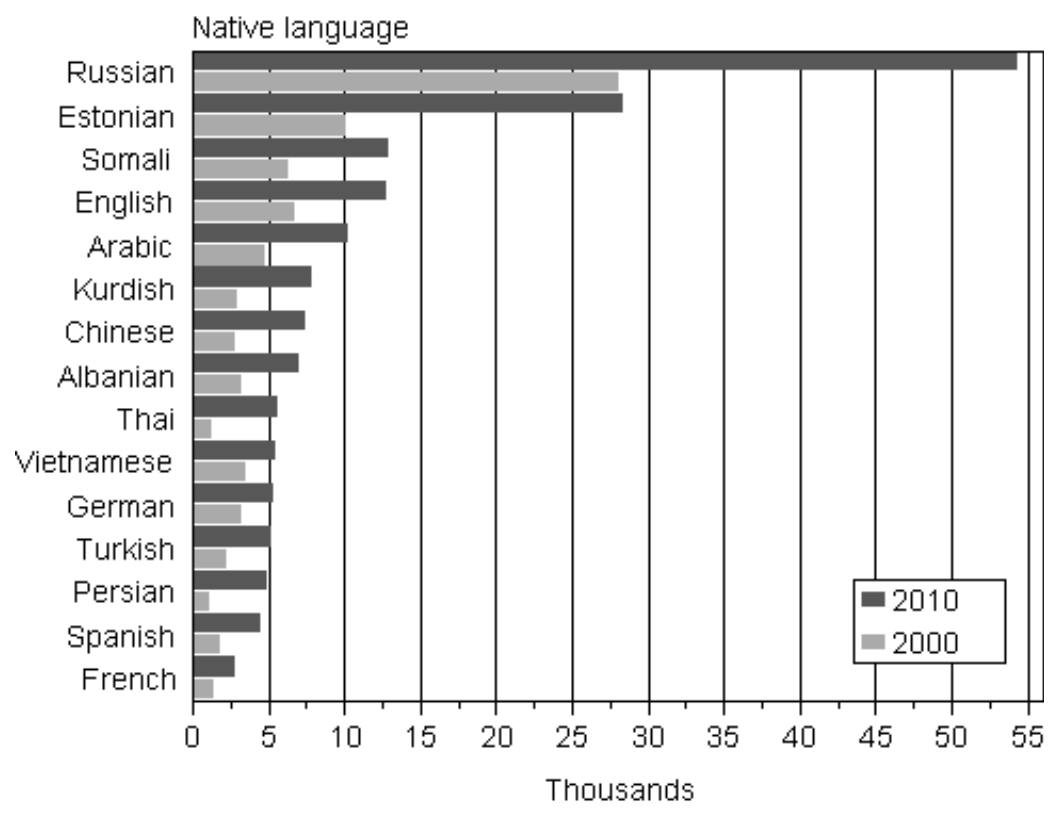

Figure 1. The largest immigrant groups by L1 in 2000 and 2010 (Statistics Finland 2011) 
From these statistics, it is evident that the eastern and southern neighbours of Finland, Russia and Estonia, contribute to the immigrant population most. While the majority of the immigrants from Russia are returnees who have Finnish roots, many of them have had a lack of knowledge of Finnish on arrival. Immigrants from Estonia, on the other hand, predominantly speak Estonian as their L1 and thus are speakers of a language closely related to Finnish. The list of languages with the largest number of speakers also includes a number of countries with recent geopolitical conflicts in Africa, Asia and Europe.

Currently, there are immigrants in all municipalities in Finland. However, most of the immigrant population in Finland - actually every second immigrant - lives in Uusimaa, the region encompassing Helsinki and the 20 other municipalities surrounding it. The following figure is based on language statistics, and it shows clearly that of those 224,388 who report languages other than Finnish, Swedish or Sámi as their first language, more than half live in Uusimaa (Figure 2):

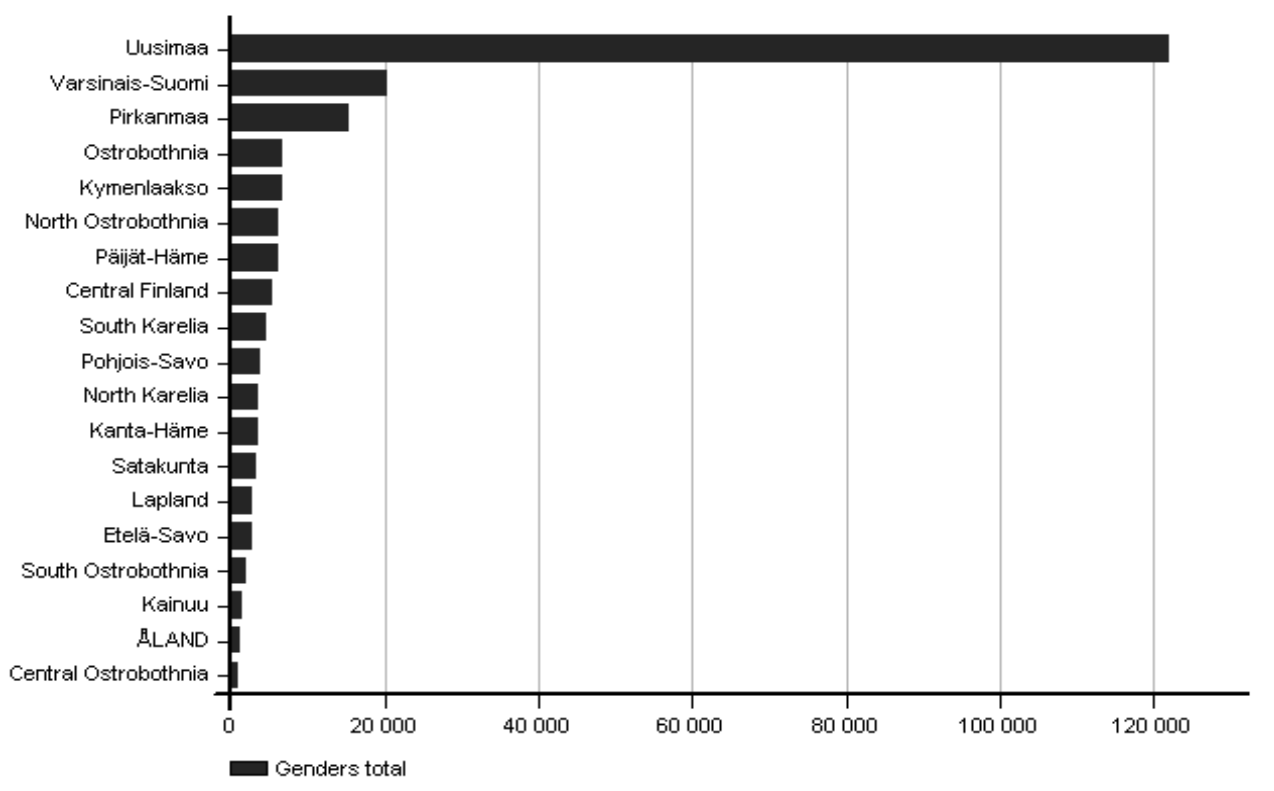

Figure 2. Immigrant population (on the basis of L1) by region in 2010 (Statistics Finland 2011) 
In other words, Figure 2 shows that there is a noticeable regional polarisation and contrast between Uusimaa and the rest of the country. Nevertheless, areas with a large concentration of immigrants, referred to as "multicultural pockets" (Bernelius 2008), are found in several cities. Furthermore, polarisation occurs in the largest cities and as a result, variation between schools can be considerable. In Helsinki, for example, some areas have student populations that are $40 \%$ plurilingual, whereas in some other areas in the capital, less than a per cent of the students has an immigrant background. If the current trend continues, it has been projected that by 2025 , every fourth student in Helsinki will come from an immigrant background (Bernelius 2008).

\section{Guidelines for the education of plurilingual students}

Contrary to the other Nordic countries, Finland is an officially bilingual country. It could therefore be anticipated that this prior experience of managing multilingualism could be useful as linguistic diversity multiplies, in effect providing a head-start over other countries facing similar challenges. This article examines whether this is the case by studying how language education policies are implemented in relation to immigrant students in Finland today.

Central documents guide schools in their work with plurilingual students. Documents such as the current national core curriculum (NBE 2004) establish the goal of immigrant education as functional bilingualism. Moreover, one of the main missions of the basic education (ages 7-16) is declared to be to "support each pupil's linguistic and cultural identity and the development of his or her mother tongue" (NBE 2004: 12). This highly ethical objective can be considered to be quite ambitious if one takes into account that an increasing number of students in Finnish schools are plurilingual. Similar ideals are presented in the most recent development plan for education and research, published by the Finnish Ministry of Education:

All pupils must be able to maintain and develop their mother tongue in addition to learning Finnish or Swedish. [...] Measures will be taken to support the equal provision of in- 
struction preparing for basic education, the teaching in the mother tongue and the teaching of Finnish or Swedish as a second language. (Ministry of Education 2008: 47)

The national core curriculum defines the conditions for the provision of Finnish as a second language in the following way:

Pupils whose native language is not Finnish, Swedish or Sámi receive instruction in Finnish as a second language either entirely or partially in place of the syllabus for mother tongue and literature when Finnish is the mother tongue. The extent of the instruction is decided upon in the curriculum. (NBE 2004: 95)

In other words, at least some Finnish as a second language needs to be taught to those students who are in need of it. Furthermore, it is mentioned that FSL instruction is meant for the student whose "skill in Finnish or Swedish is not viewed as being on a par with that of the native speakers in all areas of language proficiency" (NBE 2004: 34). Somewhat contrasting to this is the statement that instruction in L1 shall be arranged only according to the possibilities:

As possibilities allow, immigrants also receive instruction in their own native tongues. (NBE 2004: 34)

\section{The project}

The National Board of Education has conducted several surveys on the educational arrangements tailored for students from immigrant backgrounds (e.g. Korpela 2006, Kuusela et al. 2008), and a wealth of information is available that is based on questionnaires and interviews made with, for example, headmasters of schools. In most surveys, however, a central group of stakeholders - teachers - have not been consulted sufficiently, nor have their experiences and expertise been the focus of studies.

For our study entitled How is multilingualism perceived and practised in schools, teachers were chosen as the target group for several reasons. First, we wanted to complement the picture drawn thus far with the teachers' point of view. Second, our ob- 
jective was to study their professional development and linguistic awareness, as they contribute in creating the school's linguistic climate, either by supporting or ignoring plurilingualism. Third, we consider that teachers are able to provide valuable information beyond the statistics, as they encounter the practices of the whole school in their daily work. In their interface position between the educational organisation and the students, they can make observations about the attitudes and beliefs present at their workplace, as well as the progress made by their students, and can then relate these to the language programmes implemented there.

While giving lectures at various in-service training programmes, we had been informed of a number of incidents that had taken place at schools that concerned the teachers. To determine whether these cases were problems of merely one school or if they were more commonly found throughout the country, we decided to study this matter in more detail. We developed a questionnaire with 75 statements designed so that they reflect a large variety of concerns and conflicts that had been reported to us. The respondents were then asked to evaluate the familiarity of the described phenomena by reporting how frequently they occurred in their school environment. In addition to reacting to the provided statements, the respondents could freely comment on any of the topics and thereby give additional information on their viewpoints.

We activated the web-survey for a limited period of time at the end of 2008. To establish contact with teachers with plurilingual students, we used various email lists as a starting point, for example, a list of FSL teachers and a list of municipal coordinators of immigrant education. We aimed to obtain answers from as representative a group of teachers as possible, and from various parts of the country. A total of 217 teachers responded to the questionnaire. All of them had plurilingual students in their classes, and approximately $90 \%$ worked in basic education (ages 7-16), the vast majority of them in primary schools. The majority of those who responded were teachers of Finnish as a second language, which was the most common occupation, but other types of teachers also gave their viewpoints in the survey, such as class teachers, special educationists and teachers of Finnish as a mother tongue. Most of the respondents worked in a fairly new field: on average, they had taught immigrants for 7.9 years, but $32.7 \%$ merely for $1-5$ years, and $15.2 \%$ for less than a year. The majority had experience 
ranging from a few to as many as dozens of immigrants, whereas the minority had taught a hundred or more students from immigrant backgrounds. The geographic distribution of the respondents was similar to that of the immigrant population (see Figure 2): most of them resided in the region of Uusimaa and other growing population centres in Finland, but the data also included responses from small municipalities. Thus, the picture emerging on the basis of our data reflects various stages of experience, varying among individual teachers, schools and municipalities.

\section{How is linguistic diversity dealt with at schools?}

In this section, we will first discuss to what extent school communities are currently aware of their students' language backgrounds. The aims stated in the core curricula set the expectations quite high, as it is declared that the development of each student's first language should be promoted (NBE 2004: 12). Another new challenge met by many Finnish schools is the need to communicate with parents who have moved to Finland from another country. While it is apparent that some language services are needed if the parents have arrived recently, the question is whether the schools adjust their ways of disseminating information or whether they continue to inform the families in one language only. After providing examples of these practices, we will examine the range of usage allowed for immigrant languages in schools. Whereas many schools present themselves as multilingual, we will attempt to determine whether there is actually space for the variety of languages brought to the schools by the students.

\subsection{Awareness of language background}

It could be expected that the visibility and recognition of the various languages in Finnish schools have grown alongside the increasing immigration into Finland. However, according to our data, this is not the case. As many as $68 \%$ of the respondents ${ }^{2}$

\footnotetext{
${ }^{2}$ This percentage comprises the answers given for three categories: sometimes, often and always. The scale used was $1-5$, where $1=$ "never", 2 = "seldom", 3 = "sometimes", 4 = "often" and 5 = "always". In addition, one category was labeled 0 , which the respondents could select when they were not familiar with the phenomenon in question.
} 
reported that their schools do not possess enough information on the language background of their students (see Figure 3):

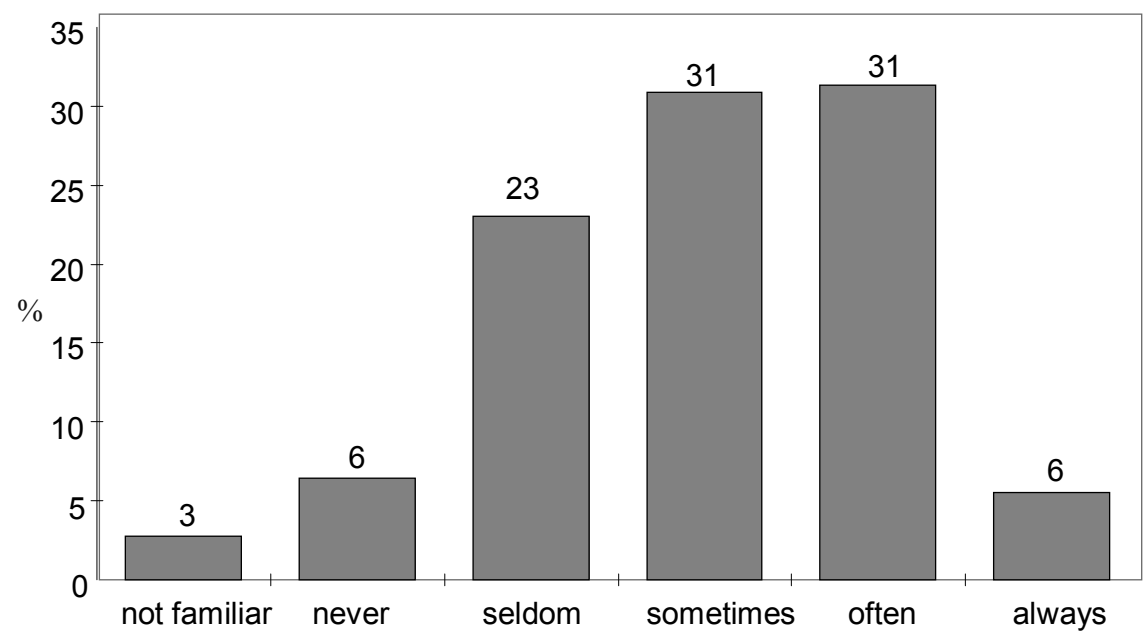

Figure 3. Statement: "School has too little information concerning the language background of its students."

In addition, more than a half of the respondents reported that their schools have provided them with too little information on the students' language background. This seems to imply that schools may have this information somewhere, but for some reason it never reaches the teachers in need of it. For instance, one respondent commented: "Information is not transferred from one official to another."

It also appears to be common that the information that the schools have is inaccurate. One explanation for the inaccurate or missing information is that the programme used to register the background information about students does not have an option for all immigrant languages, and as one respondent remarked, not even for Romani. This state of affairs is clearly in contrast with the goals set in the national curriculum which stipulate that the development of each student's first language is supposed to be supported. Another explanation for the missing information is self-report. The parents have the right to declare any language both in the official register and for the use of the municipality. Some respondents had the experience of parents who did not dis- 
close the language used at home and who instead gave Finnish as their children's first language, for fear that the children's true L1 could have undesirable consequences for their education. For the municipalities, the unreported languages mean a loss in resources, as the municipalities receive a special government subsidy for all the students with a language other than Finnish or Swedish as their L1. In other words, it would clearly be in the municipalities' interest to inform parents of the significance of accurately reporting the language situation of their families.

\subsection{How to communicate with immigrant parents?}

The Finnish school system aims at respecting parents as co-workers of teachers and as active participants in any schoolrelated projects. As a consequence, it is highly valued that fluent communication and informal relationships with the homes are established. In addition to regular meetings with parents, many means of informing families and communicating without barriers have been developed. For example, e-mail lists and computerbased feedback systems are commonly in use, in addition to the more traditional written notes and newsletters sent to the students' homes.

Multilingualism in the classrooms presents new challenges: not all parents speak or read and write Finnish fluently enough to cope with messages mediated through this language. According to our findings, many schools attempt to use as many L1s as possible when informing families. In addition, when contacting the parents, some schools use syntactically and lexically simplified Finnish ("Plain Finnish"). However, all school staff should be aware of these means and be willing to employ them, but this is not always the case. It also takes time to develop well-functioning practices in this respect. The typical problems concern finding a translator in each language in time and negotiating meeting schedules with the parents and interpreters. The varying challenges and solutions found for them are illustrated by the following comments:

We still have much work to do with translating and simplifying our newsletters. 
Newsletters are sent out in as many languages as possible.

To order interpreters and to negotiate suitable schedules with them is experienced as a complicated matter.

Some individual respondents found it unnecessary to use any other language than Finnish when communicating with immigrant homes. While these were rare exceptions, they indicate that there is no complete consensus on these issues among the teachers, either. Relying on the formulations of the constitution, one respondent argued that only those languages having an official status in the legislation are to be used:

The Finnish school cannot and should not become a service centre that translates all the notices in all ten languages and thus accustoms the parents to constant "ready meals" instead of making them actually try to become part of Finnish society and learn some everyday Finnish. In case their language skills are insufficient for understanding the notices sent by the school, it is their duty to find a translator. There are certainly opportunities for that. The Finnish school operates in Finnish; if requested, also in Swedish and Sámi.

Such views show that mainstreaming appears to be an attractive option for some teachers. Mainstreaming looks easy and practical, and in a certain sense it appears even democratic. Nevertheless, the notions underlying these attitudes may be rather nationalistic and restrictive when concerned with the expression of multilingual identities.

\subsection{Use of $L 1$ at school}

In 2007, it was reported that one school in Helsinki had prevented students from using their own languages in the classroom. After that, the school received specific instructions to stop doing this from the Education Department of the City of Helsinki (Vähäsarja 2007). In the public debate that followed, it was emphasised that this incident was rare. But how rare was it in practice? Are immigrant students allowed to use all their languages on the school premises and for all the functions they want to? 
Over a half of the respondents (55\%) claimed students are "never" forbidden to use their own language during recess, whereas $18 \%$ had no experience of this phenomenon. Nonetheless, about every fourth respondent had encountered that phenomenon in their schools (Figure 4):

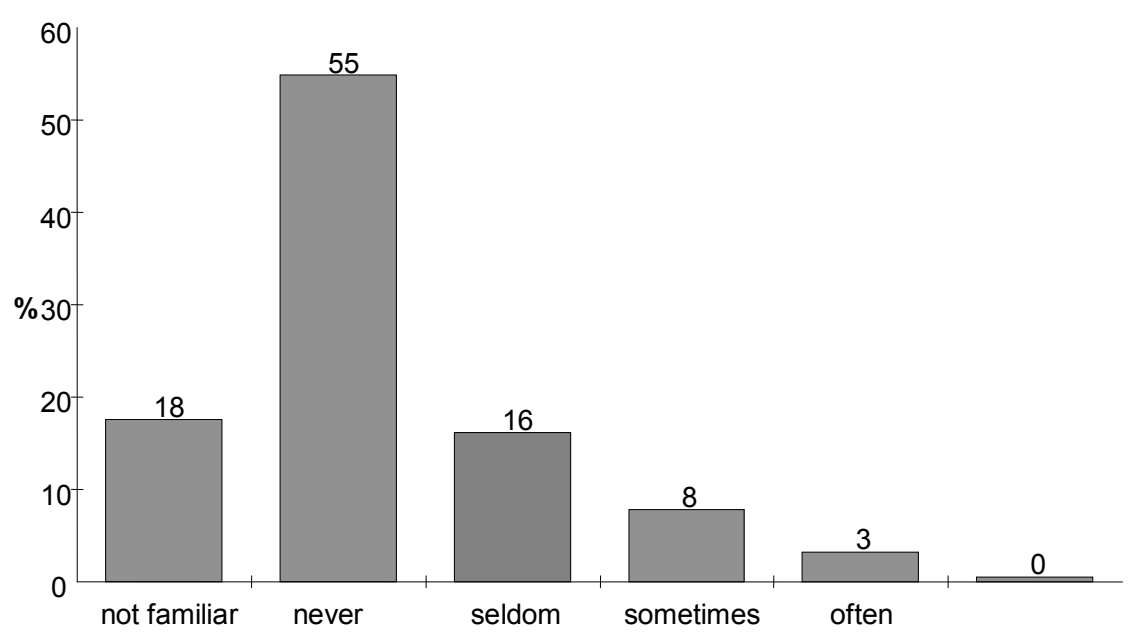

Figure 4. Statement: "The students are forbidden to use their own language with speakers of the same language during school recesses."

In their responses to this statement, the respondents were fairly unanimous. Thus, the grassroots language policy of Finnish schools seems to include the following tacit rule: it is not permitted to openly restrict the use of other languages. Instead, it appears to be acceptable to guide students to "practice their Finnish" during their school recess. Indeed, the use of L1 in the classroom can be forbidden more openly: as many as $41 \%$ of the respondents declared that at least sometimes students are prevented from using their L1 in group work or when offering advice to other students. Some respondents commented that the restrictions to use L1 are well motivated, for example, when suspecting that students have been teasing each other or using their language as a tool of power in other ways.

The linguistic climate of Finnish schools can be further illustrated by the following comments: 
In some schools it is forbidden to use one's own language. Luckily, in my current school this is not the case, but students are also advised to use their own language in the class if there are several speakers of the same language. However, some parents have denied their children to do so.

It is fine to advise another student in the class, but all irrelevant discussions are forbidden in all languages.

We have done that when there has been evidence that language switching has occurred in order to tease others.

\section{Teaching arrangements in L1 and FSL}

In this section, we will first examine to what extent instruction in the students' L1s is currently offered and how willingly students choose to attend that instruction. In addition, we will study the availability of FSL instruction and the choices students and their parents make. It is a commonly observed phenomenon in immigrant contexts that some students and parents prefer mainstreaming, even though tailored teaching arrangements are available (see e.g. Cummins 2000, Schwartz 2010). We will make an attempt to illuminate the underlying reasons for this tendency.

\subsection{Is L1 instruction available?}

In contrast to many other European countries, the L1 instruction in Finland is backed by public funding (cf. McPake et al. 2007, Eurydice 2009). This means that the municipalities receive state funding for groups of at least four students, and groups can be formed of students from several schools and even from various municipalities. Under these conditions defined by the National Board of Education (Opetushallitus 2010), it could be anticipated that it would be easy to offer L1 instruction in any of the languages entitled for the state subsidy. In practice, however, municipalities decide whether and how L1 instruction is to be arranged. ${ }^{3}$

\footnotetext{
${ }^{3}$ For example, the municipalities decide how many students actually need to be enrolled before a group is formed. In several municipalities, the minimum number of students has been set at eight.
} 
As our results show, in some municipalities L1 instruction can be considered a default practice and a standard procedure:

If the student's L1 is known, instruction is organised if possible.

Instruction is organised, if there are at least four students in the language group.

In our school the first languages are appreciated. Students go to these classes in a regular manner.

All your statements on this topic seem quite unbelievable in our municipality, where these matters have been properly taken care of for several years.

Nonetheless, other experiences were also reported:

No mother tongue instruction is given, and I don't understand why! Language groups are big enough for our school to receive the state subsidy.

In our municipality, there is no instruction in Vietnamese, even though there are five Vietnamese-speaking students. The headmaster is not willing to organise it because it demands co-operation with other schools and it eats up the hourly resources of the school (?).

Altogether, instruction is given in approximately 50 languages (Opetushallitus 2011). As only about a half of the students receive instruction in their first language, the aim mentioned in the core curriculum is far from reality. The practices of the municipalities vary: some organise it as soon as the prerequisites are fulfilled, but some do not do this even when there is a sufficient number of students. One explanation for this is that there is no obligation to organise or take part in this instruction; it is voluntary for the organisers of education, and it is voluntary for the students. 


\subsection{Attitudes towards L1 instruction}

The voluntary nature of L1 instruction is also manifested in the attitudes expressed by the students. As is shown by Figure 5 , it was reported by two-thirds of the respondents $(65 \%)$ that students do not take part in L1 instruction at least sometimes in their schools, even though it is organised:

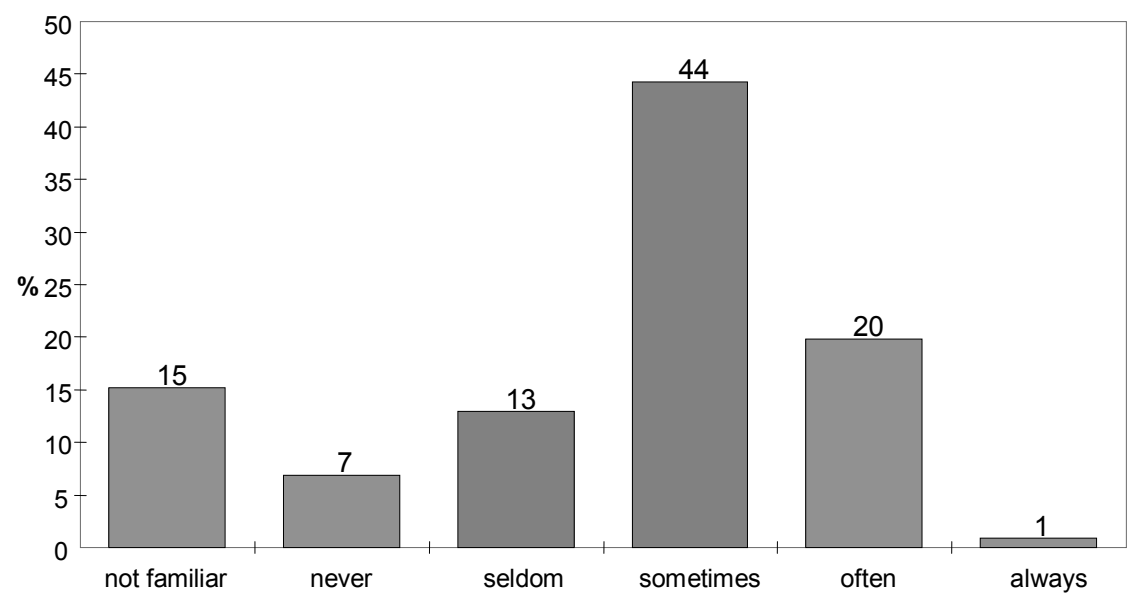

Figure 5. Statement: "L1 instruction is organised, but the student doesn't attend it."

According to the teachers, students decline to participate in L1 instruction, since their parents want them to study Finnish instead of their L1. Indeed, more than half of the respondents $(52 \%)$ agreed with this statement. In other words, while the school tries its best to promote its students' plurilingualism, the parents' aspirations seem to work against this idea.

On the other hand, the students' unwillingness to participate in L1 instruction and their parents' doubts about its value can be explained by its low status. First, L1 is studied on a voluntary basis for 1-2 hours per week. Second, instruction is usually given late in the afternoon. In this way, the practices have set L1 instruction apart from formal instruction in the compulsory languages (Finnish, English and Swedish). The following comments indicate that there are quite a few practical problems with the arrangements: 
If the instruction is not given in our school, the students often decide not to attend it.

L1 instruction doesn't interest all families, and therefore the children are not sent there even if it were available. In addition, there are problems with timetables that make it difficult to participate in L1 instruction.

The reasons can be found in the long afternoon hours, the excessive heterogeneity of the groups and in protests against the personality or the ethnic background of the teacher.

\subsection{Is $\mathrm{L} 2$ instruction available?}

According to the respondents, instruction in Finnish as a second language is usually offered for those who need it. However, as Figure 6 illustrates, some students who have been identified by the teachers as needing FSL instruction do not receive it.

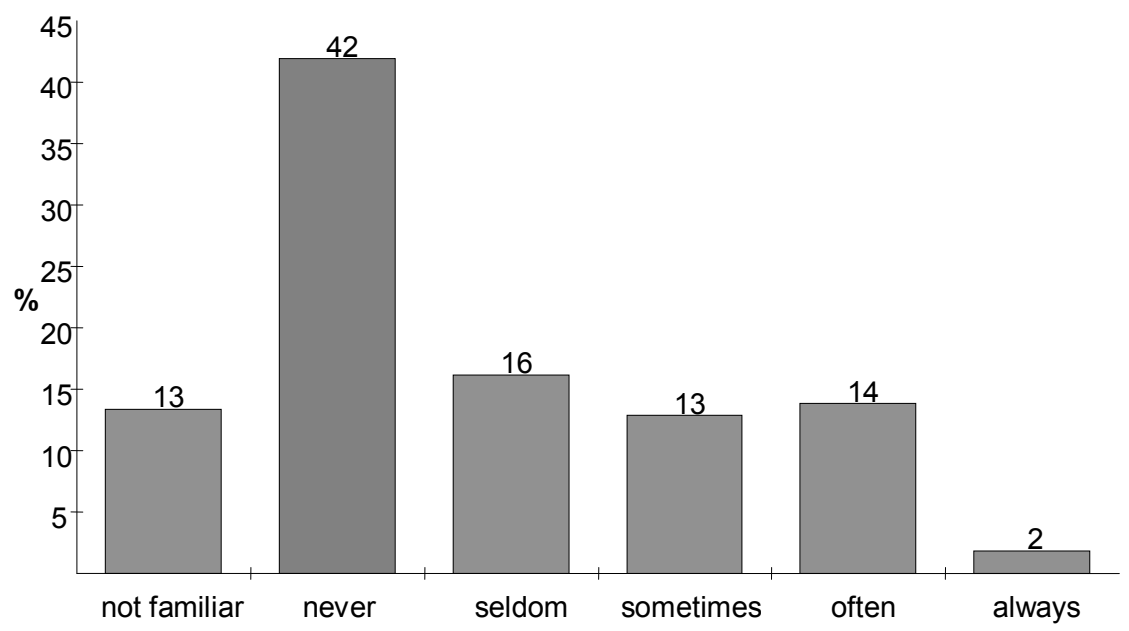

Figure 6. Statement: "The student clearly needs FSL instruction, but doesn't receive it."

The large-scale variation is observable and well illustrated in the comments given by the respondents of our survey. As the following quotations clearly show, practices still vary, and a con- 
tinuum of practices can be recognised: some teachers are fighting for the students' right to receive FSL instruction, whereas some are witnessing the challenges of a beginning stage of organising it, and some already have well-functioning practices in their schools:

Lack of language skills is a common topic at our meetings, but there is no willingness to give resources for FSL instruction.

In our municipality, there is FSL instruction only in one school, and there are 10 schools altogether.

There are three full-time FSL teachers in our school.

The following comments reveal the crucial role that the local decision-makers have:

There is a crying need for FSL, but according to our head of education, there "isn't much call for it".

At the beginning of the semester, the headmaster ordered that only a handful of students are entitled to FSL instruction. A much greater number would need it.

The headmaster may be of the opinion that there is no need for FSL instruction, and, therefore, it is not organised. He or she may also restrict the access to FSL classes by setting such criteria as having very modest Finnish language skills for those who are allowed to participate.

It is evident that the individual needs have not yet been adequately fulfilled. According to a national study (Korpela 2006), $25 \%$ of the students in need of FSL instruction did not receive it. Most students, $60 \%$, were offered some FSL teaching, usually one hour per week, and $12 \%$ received the full number of hours. According to the latest study by the National Board of Education (Kuusela et al. 2008), the situation remains the same.

The status of FSL instruction continues to be unclear in school communities, although this special syllabus was launched in the national core curriculum in 1994, and the concept of "Finnish as a second language" is relatively well-recognised among 
teachers. The reason for the unclear status has to do with the fact that there is no obligation to organise FSL instruction, even though the national core curriculum declares that immigrant students will receive such instruction. The municipalities are obliged to organise instruction in Finnish, but they do not have to choose the FSL syllabus.

A recent change in the conditions for funding may improve the students' future opportunities for receiving FSL instruction. Since January, 2010, a state subsidy has been offered for all the students in need of second language instruction during their first six years at school. Until year 2010, such a subsidy was set to cover the first four years after arrival only (Opetushallitus 2010). The extended time facilitates flexible arrangements according to the students' individual needs, and at school level, it makes possible the long-term planning of FSL instruction.

\subsection{Attitudes towards $L 2$ instruction}

Teaching arrangements that are not obligatory for the municipalities are closely related to attitudes. As shown above, the decision-makers in the municipalities have an important role in determining whether FSL instruction will be offered and how it will be organised. Furthermore, our results indicate that among other teachers, FSL is not always considered to be real teaching that corresponds to Finnish L1. Instead, teachers of other subjects may expect, for example, that students prepare for the exams of their own subjects during the FSL classes. Some other teachers may even take the students away from the FSL instruction, as they think they have something more important to teach them:

The class teacher "takes" his/her student away from FSL classes every now and then, because s/he has more meaningful activities to offer.

One might say that the student has to be present in "real Finnish L1 classes" to avoid lagging behind.

Finnish as a second language is considered to be between special education and remedial teaching. 
Such attitudes expressed by teachers are easily reflected in the students' willingness to attend FSL classes. However, ignorant or negative attitudes towards FSL have not only been observed among teachers. As noticed in other countries as well, it is typical that immigrant parents, unless correctly informed, may also treat all tailor-made arrangements as stigmatising. As a result, it is rather often parents prefer mainstream Finnish to be taught to their children and not FSL (Figure 7):

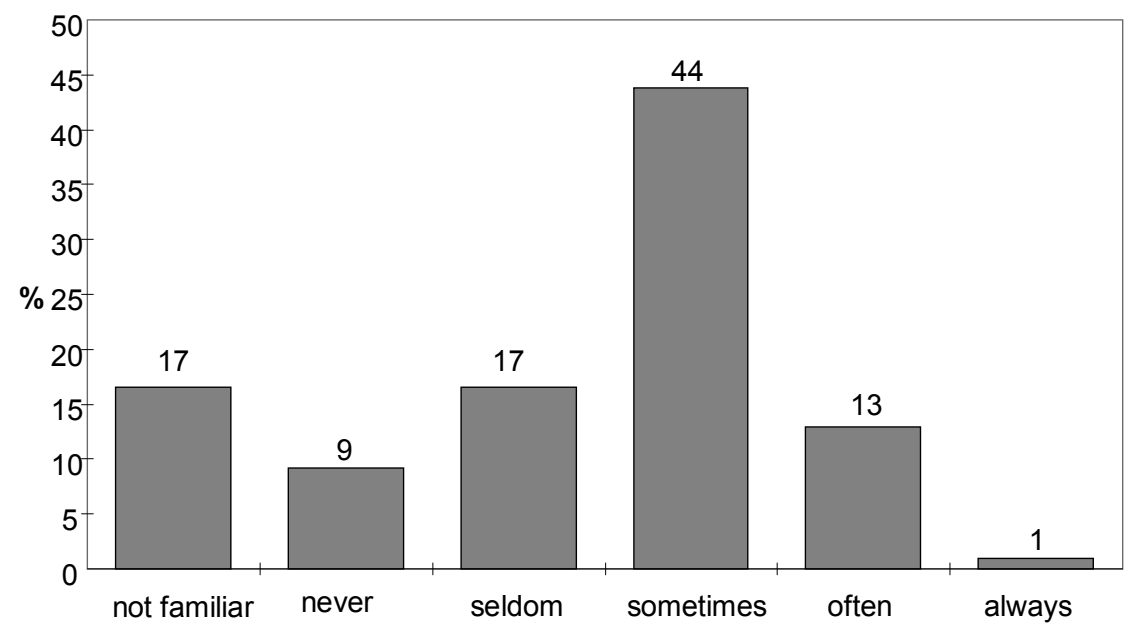

Figure 7. Statement: "Parents want their child to study Finnish as L1 and not as L2."

As the following comments reveal, the preference for mainstream arrangements is often expressed by Estonian and Russian parents. This could be seen against some previous findings on some immigrant families' deliberate choice to integrate so well that children become indistinguishable from the majority and are not therefore labelled as immigrants (e.g. Jasinskaja-Lahti 2000, Iskanius 2006, Rynkänen and Pöyhönen 2010). Furthermore, connotations and expectations connected to the educational system of the country of origin may get transferred to the new country of residence:

Estonian- and Russian-speaking parents very often want their children to learn Finnish as an L1. 
Some [parents] fear that a grade in FSL in the school report will become an obstacle in their children's further education; some don't want to be different from others; for some FSL means "disgrace" - the child has insufficient skills in Finnish and has to participate in FSL classes.

Many teachers have encountered parents who argue for mainstream Finnish L1 instruction by referring to equality and democracy. If the parents represent such an ideology that educational democracy means equal arrangements for all, it may be difficult to convey to them the Nordic concept of an educational equality which aims at ideal learning opportunities for all through educational arrangements tailored according to individual needs (see e.g. Välijärvi et al. 2007). In the last comment to be presented here, one of the respondents reports on a successful awareness-raising process:

When I started at my current work place, I had to work hard to make the parents accept that their children participate in FSL classes. Now after one year, the attitudes have changed, and some parents have even thanked me for teaching FSL to their child.

\section{Concluding remarks}

During the past twenty years, teaching arrangements have developed alongside the accumulated experience in encountering plurilingual students. In addition, multilingualism has become an inevitable part of the daily life at Finnish schools. Specifically in schools with extensive experience of these issues, good practices have been established and also disseminated further afield (see e.g. Immonen-Oikkonen and Leino 2010). Our results show, however, that instruction in L1 or FSL is not organised everywhere, nor are the aims and contents of these curricula clear for everyone. Furthermore, it appears that monolingualism is still a common way of living in the daily life at Finnish schools. Therefore, it seems that Finland's history as an officially bilingual country has not given Finland a head-start over the other Nordic countries, but the steps Finland has taken in developing, for example, language education policies, teacher education and 
teaching arrangements seem similar to the ones found earlier in Sweden, Norway and Denmark (see e.g. Taguma et al. 2009, Taguma et al. 2010, Nusche et al. 2010).

To improve the current situation, the languages spoken by plurilingual students should be given the space to be more visible and audible within the school environment. It is important to implement such instruction and assessment practices which encourage the students to rely on their multilingual resources. Furthermore, it is necessary to invest a lot in the means of communication with parents to prevent misunderstandings concerning schooling, in general, and the needs and goals of first and second language instruction, in particular.

There are several ways to tackle these challenges. In order to support the developing plurilingual repertoires that the students have, recognition of the value of all the languages in use at school is needed. The schools can, for example, adopt an approach similar to the one initiated by a primary school in London. In the project "Language of the Month", all students learn some simple phrases of each others' languages (McPake et al. 2007: 41). As the project is built on community-based resources, the parents have become more actively involved in school activities. Therefore, they are also better informed about the expectations the school has, and it has been easier for them to support their children in their school work. For the teachers, initiatives like this can be eye-openers. Instead of seeing the students from immigrant backgrounds in terms of poverty of skills, they can start to realise that these students should be considered as a source of new wealth that resonates through the society.

The results of our web-survey also suggest that there is a gap between the national language education policy and its local interpretations and implementations. The municipalities and even individual schools are entrusted to execute the language education policy in practice, and they obviously engage in this differently. What plays an especially central role in defining the educational settings in which students from immigrant backgrounds go to school is the local authorities' awareness of and attitudes towards issues related to immigration.

As the core value of Finnish education is equal opportunities for all, this central target also has to be considered from the point of view of the students from immigrant backgrounds. To prevent inequity, an obligation to organise tailored second 
language instruction for this target group is obviously needed at the national level. Such a change, affecting local educational arrangements, should also be accompanied by adequate in-service training for both teachers and organisers of education. Finally, all the members of school communities should be made aware of the fact that students from immigrant backgrounds are part of the plurilingual resources of schools and societies. As such their skills need to be promoted - and not ignored.

\section{Acknowledgements}

We would like to thank the two anonymous reviewers for their valuable comments on the manuscript of this article. The article has partially (Minna Suni) been written in the research project Dialogues of appropriation: Dialogical approaches to language learning and teaching, funded by the Academy of Finland and directed by Prof. Hannele Dufva.

\section{Addresses:}

Sirkku Latomaa

School of Language, Translation and Literary Studies

33014 University of Tampere

Finland

E-mail: sirkku.latomaa@uta.fi

Minna Suni

Department of Languages

P.O. Box 35

40014 University of Jyväskylä

Finland

E-mail: minna.suni@jyu.fi

\section{References}

Bernelius, Venla (2008) Lähi(ö)koulu - Helsingin koulut ja kaupunginosat EU:n Urban II- ohjelman kouluhankkeissa. (Tutkimuksia, 3.) Helsinki: Helsingin kaupungin tietokeskus.

Cummins, Jim (2000) Language, power and pedagogy: bilingual children in the crossfire. Clevedon: Multilingual Matters. 


\section{Sirkku Latomaa and Minna Suni}

Eurydice (2009) Integrating immigrant children into schools in Europe. Brussels: Eurydice.

Immonen-Oikkonen, Pirjo and Anne Leino, eds. (2010) Monikulttuurinen kouluyhteisö. Helsinki: Opetushallitus.

Iskanius, Sanna (2006) Venäjänkielisten maahanmuuttajaopiskelijoiden kieliidentiteetti. (Jyväskylä Studies in Humanities, 51.) Jyväskylä: University of Jyväskylä.

Jasinskaja-Lahti, Inga (2000) Psychological acculturation and adaptation among Russian-speaking immigrant adolescents in Finland. (Social Psychological Studies, 2.) Helsinki: University of Helsinki.

Korpela, Helena (2006) Suomi tai ruotsi toisena kielenä -opetuksen järjestäminen perusopetuksessa. Selvitys 2005. Helsinki: Opetushallitus.

Kuukka, Katri (2009) Rehtorin eettinen johtaminen monikulttuurisessa koulussa. "Sen yhteisen hyvän löytäminen." (Acta Universitatis Tamperensis, 1435.) Tampere: Tampereen yliopisto.

Kuusela, Jorma, Aulikki Etelälahti, Åke Hagman, Raisa Hievanen, Krister Karppinen, Leena Nissilä, Ulla Rönnberg, and Marjatta Siniharju (2008) Maahanmuuttajaoppilaat ja koulutus - tutkimus oppimistuloksista, koulutusvalinnoista ja työllistymisestä. Helsinki: Opetushallitus.

Laaksonen, Annele (2008) Maahanmuuttajaoppilaat erityiskouluissa. (Annales Universitatis Turkuensis, C 262.) Turku: Turun yliopisto.

Lasonen, Johanna and Mia Halonen, eds. (2009) Kulttuurienvälinen osaaminen koulutuksessa ja työelämässä. (Kasvatusalan tutkimuksia, 43.) Turku: Suomen kasvatustieteellinen seura.

Martikainen, Tuomas (2007) "Maahanmuuttajaväestön sukupuolittuneisuus, perheellistyminen ja sukupolvisuus". In Tuomas Martikainen and Marja Tiilikainen, eds. Maahanmuuttajanaiset: kotoutuminen, perhe ja työ, 38-67. Helsinki: Väestöliitto, Väestöntutkimuslaitos.

McPake, Joanna, Teresa Tinsley, Peter Broeder, Laura Mijares, Sirkku Latomaa, and Waldemar Martyniuk (2007) Valuing all languages in Europe. Graz: European Centre for Modern Languages.

Ministry of Education (2008) Education and research 2007-2012. Development Plan. Helsinki: Ministry of Education.

NBE (2004) National core curriculum for basic education 2004. Helsinki: National Board of Education.

Nusche, Deborah, Gregory Wuzburg, and Breda Naughton (2010) OECD reviews of migrant education: Denmark. Paris: OECD.

Opetushallitus (2010) Valtionavustus vieraskielisten sekä saamen- ja romanikielisten oppilaiden ja opiskelijoiden esi- ja perusopetuksen sekä lukiokoulutuksen järjestämiseen vuonna 2010. (Tiedote, 4.) Helsinki.

Opetushallitus (2011) Maahanmuuttajien koulutus Suomessa - tilannekatsaus. (Raportit ja selvitykset, 3.) Helsinki: Opetushallitus. 
Rynkänen, Tatjana and Sari Pöyhönen (2010) "Eri-ikäisinä muuttaneet venäjänkieliset nuoret. Suhde kielen ylläpitämiseen, kielenoppimiseen ja integroitumiseen". In Tuomas Martikainen and Lotta Haikkola, eds. Maahanmuutto ja sukupolvet, 175-192. (Tietolipas 233.) Helsinki: Suomalaisen Kirjallisuuden Seura and Nuorisotutkimusverkosto.

Schwartz, Mila (2010) "Family language policy: core issues of an emerging field”. In Li Wei, ed. Applied linguistics review, 171-192. Berlin and New York: De Gruyter Mouton.

Statistics Denmark (2011) Statistical yearbook 2010. Copenhagen: Statistics Denmark.

Statistics Finland (2011) Population structure. $<$ http://pxweb2.stat.fi/database/ StatFin/vrm/vaerak/vaerak_en.asp >. Accessed March 18, 2011.

Statistics Iceland (2011) Population. <http://www.statice.is/Statistics/Population>. Accessed March 15, 2011.

Statistics Norway (2011) Innvandrerbefolkningen. <http://www.ssb.no/innvbef/>. Accessed April 28, 2011.

Statistics Sweden (2011) Befolkningsstatistik. <http://www.scb.se/Pages/ ProductTables__25795.aspx>. Accessed March 7, 2011.

Suni, Minna and Sirkku Latomaa (forthcoming) "Dealing with increasing linguistic diversity in schools: the Finnish example". To be published in Jan Blommaert, Sirpa Leppänen, Päivi Pahta, and Tiina Räisänen, eds. Dangerous multilingualism.

Taguma, Miho, Claire Shewbridge, Jana Huttova, and Nancy Hoffman (2009) OECD reviews of migrant education: Norway. Paris: OECD.

Taguma, Miho, Kim Moonhee, Satya Brink, and Janna Teltemann (2010) OECD reviews of migrant education: Sweden. Paris: OECD.

Vähäsarja, Irina (2007) Helsinkiläiskoulu kielsi äidinkielen puhumisen tunneilla. Helsingin Sanomat December 21.

Välijärvi, Jouni, Pekka Kupari, Pirjo Linnakylä, Pasi Reinikainen, Sari Sulkunen, Jukka Törnroos, and Inga Arffman (2007) The Finnish success in Pisa - and some reasons behind it 2. Jyväskylä: University of Jyväskylä, Institute for Educational Research.

\section{Kokkuvõte. Sirkku Latomaa ja Minna Suni: Mitmekeelsus Soome} koolides: poliitika ja praktika. Artikli eesmärk on anda ülevaade mitmekeelsusest Soome koolides. Artikli fookuses on paljukeelsete (st immigranttaustaga) õpilaste õpetajate kogemused. Uurimuse andmed on kogutud veebipõhise küsitluse teel. Küsitlus käsitles teemasid nagu keelte staatus ning paljukeelsete õpilaste õppekorraldus. Lisaks küsimustele vastamisele võisid vastanud vabalt kommenteerida mis tahes teemat, 
mis täiendasid kvantitatiivseid andmeid, tuues välja mitmeid kasulikke vaatenurki. Mitmed vastanud teatasid, et nende tööperioodi jooksul on tehtud märgatavaid edusamme paljukeelsete õpilaste õppekorralduse osas. Teisest küljest näitasid aga uuringu tulemused, et mitmed väljakutsed siiski jäävad - nagu näiteks ühtsema K1- ja K2- õppe tagamine. Mõnedes Soome piirkondades on sellised programmid toiminud hästi, teistes on aga õppekorralduse eest vastutajad alles nüüd teadvustanud üha kasvavat mitmekeelsust nende koolides.

Võtmesõnad: mitmekeelsus, keeleharidus, immigratsioon, keelde suhtumine, esimene keel, teine keel 